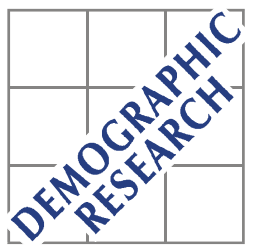

Demographic Research a free, expedited, online journal

of peer-reviewed research and commentary in the population sciences published by the Max Planck Institute for Demographic Research

Konrad-Zuse Str. 1, D-18057 Rostock · GERMANY

www.demographic-research.org

DEMOGRAPHIC RESEARCH

VOLUME 25, ARTICLE 10, PAGES 337-370

PUBLISHED 2 AUGUST 2011

http://www.demographic-research.org/Volumes/Vol25/10/

DOI: $10.4054 /$ DemRes.2011.25.10

Research Article

\title{
Challenges in moving from macro to micro: Population and family structures in ageing societies
}

\section{Katharina Herlofson \\ Gunhild O. Hagestad}

This publication is part of the proposed Special Collection "Intergenerational family ties in Europe: Multiple linkages between individuals, families and social contexts", edited by Pearl Dykstra.

(C) 2011 Katharina Herlofson \& Gunhild O. Hagestad.

This open-access work is published under the terms of the Creative Commons Attribution NonCommercial License 2.0 Germany, which permits use, reproduction \& distribution in any medium for non-commercial purposes, provided the original author(s) and source are given credit.

See http:// creativecommons.org/licenses/by-nc/2.0/de/ 


\section{Table of Contents}

$1 \quad$ Introduction 338

2 The changing balance of young and old: An upside-down

population pyramid? 338

$3 \quad$ Macro shifts - micro changes? 341

$3.1 \quad$ Longer lives - more generations? 341

3.1.1 Mapping individuals' generational structures: Methodological

$\begin{array}{ll}\text { 3.1.2 Generational structures: Who is the anchor? } & 346\end{array}$

3.1.3 Multigenerational structures: Summing up 348

3.2 Lower fertility - fewer children to care for old parents? 349

3.2.1 Women's number of children versus mothers' number of children $\quad 350$

3.2.2 "The parent support ratio": A population level indicator with a
family level label

3.2.3 More children - more care? $\quad 353$

$\begin{array}{lll}3.2 .4 & \text { The future of parent care: summing up } & 354\end{array}$

$4 \quad$ The centrality of gender in generational research 355

$5 \quad$ Some overlooked and underexplored issues 358

6 Moving from macro to micro - summing up 360

$7 \quad$ Acknowledgements $\quad 360$

$\begin{array}{ll}\text { References } & 361\end{array}$ 


\title{
Challenges in moving from macro to micro: Population and family structures in ageing societies
}

\author{
Katharina Herlofson ${ }^{1}$ \\ Gunhild O. Hagestad ${ }^{2}$
}

\begin{abstract}
Assumptions are often made about how population ageing on the macro level has altered generational structures of families at the micro level. The purpose of this paper is to increase the awareness of challenges and potential pitfalls in bridging the two levels. To highlight these issues, two common claims found in the literature are questioned and discussed: that increased life expectancy leads to more multigenerational family structures and that reduced fertility means fewer children to care for frail parents. To illustrate, we use population statistics and survey data from selected countries.
\end{abstract}

\footnotetext{
${ }^{1}$ NOVA - Norwegian Social Research. E-mail: kat@nova.no.

${ }^{2}$ NOVA - Norwegian Social Research. E-mail: gohagestad@gmail.com.
} 


\section{Introduction}

It is evident that the essential demographic forces that determine the size, age structure and gender mix of populations - patterns of birth and death, by age - underlie patterns of kin availability as well (Wolf 1994:149).

Families look different today than they did fifty years ago. We have added a whole generation to the structure of many families (Bengtson et al. 2003:2).

Decreasing fertility rates means that fewer children will be available to provide care for elderly parents (Tennstedt, Crawford, and McKinley 1992:603).

These three quotes identify issues discussed in this article. Among both researchers and policy makers, assumptions are made about how population ageing has altered generational ties at the family level. Most commonly, it is argued that increased life expectancy alters the generational structure of families (e.g., Bengtson, Rosenthal, and Burton 1990; Harper 2003; Véron, Pennec, and Légaré 2007) and that declining fertility means fewer children to care for older parents (e.g., Clarke 1995; Daatland and Herlofson 2003; European Foundation for the Improvement of Living and Working Conditions 1995; Monk 1983; Morrison 1990; Pickard 2002; Tennstedt, Crawford, and McKinley 1992). In this article, we highlight the complexities of issues involved to increase awareness of challenges and potential pitfalls in moving from considerations of population ageing on a macro level to implications for family structures on a micro level. Clearly, discussions of welfare policies need to incorporate both levels and recognise the possibility that they may present divergent pictures. Social scientists face the task of providing valid and comprehensible accounts of recent developments, recognising the many facets of demographic change and the limitations of our tools.

\section{The changing balance of young and old: An upside-down population pyramid?}

For most of human history, populations have formed a bottom-heavy pyramid, with children making up about one half. As is well known, population ageing brings dramatic shifts in the balance of old and young in society, due to declining mortality and fertility. If we look at the number of people 65 years and older per 100 children under 15 for selected European countries, we see that recent and projected changes are formidable. As illustrations, we have chosen a country from each of the four regions of Europe: North (Norway), West (Germany), East (Czech Republic) and South (Italy). 
All the selected countries are part of the Generations and Gender Programme of the United Nations, whose main goal is to improve the understanding of demographic and social developments in UNECE countries (United Nations 2007a).

During a period of sixty years (from 1975 to 2035), the number of people aged 65 and over per 100 children under 15 is expected to more than double in Norway, nearly triple in the Czech Republic, and almost quadruple in Germany. Italy will experience the greatest change with an increase forecasted to be more than fourfold (Table 1). Thus, Germany and Italy are expected to have more than twice as many old people $(65+)$ as children (0-14) in 2035 (United Nations 2009, medium variant). Under such conditions, we are observing a change towards an "inverted pyramid".

Table 1: Number of persons 65 years and older per 100 children under 15, selected European countries, 1975-2035

\begin{tabular}{lccc}
\hline & $\mathbf{1 9 7 5}$ & $\mathbf{2 0 0 5}$ & $\mathbf{2 0 3 5}$ \\
\hline Norway & 58 & $\mathbf{7 4}$ & 130 \\
Germany & 69 & 132 & 250 \\
Czech Republic & 59 & 96 & 161 \\
Italy & 51 & 138 & 236 \\
\hline
\end{tabular}

Source: United Nations (2009) World population prospects: The 2008 Revision Population Database. Medium variant.

The main reasons for the changing ratios of old people and children are longer lives and declining fertility. In the last quarter of the $20^{\text {th }}$ century, life expectancy at birth increased by 5 years in Norway and the Czech Republic; 8 years in Germany and Italy. By 2030-35 it is expected to increase by another $4-5$ years in all four countries (Table 2).

Table 2: $\quad$ Life expectancy at birth, selected European countries, 1970-2035

\begin{tabular}{lccc}
\hline & $\mathbf{1 9 7 0 - 1 9 7 5}$ & $\mathbf{2 0 0 0 - 2 0 0 5}$ & $\mathbf{2 0 3 0 - 2 0 3 5}$ \\
\hline Norway & 74 & 79 & 84 \\
Germany & 71 & 79 & 83 \\
Czech Republic & 70 & 75 & 80 \\
Italy & 72 & 80 & 84 \\
\hline
\end{tabular}

Source: United Nations (2009) World population prospects: The 2008 Revision Population Database. Medium variant.

At the same time that we have witnessed rising life expectancies, there has been a sharp fall in fertility rates across European countries. From the beginning of the 1970s to around year 2000, total fertility rates in Italy and the Czech Republic decreased by 
about one child (Table 3). In Germany the decline was substantial as early as the mid1970s. The German fertility rate for the $1965-1970$ period was 2.3 (data not shown); five years later it was 1.6, and it decreased further to 1.35 by $2000-2005$. Fertility change in Norway was less marked than in the other countries and the rate is projected to remain stable around 1.8-1.9 for the next 20-25 years. In the other three countries fertility rates are expected to increase. According to Goldstein and colleagues (2009) and Sobotka (2004), the main reason for this rise is that fertility postponement in many countries seems to have levelled off. Lutz, Skirbekk, and Testa (2006) on the other hand, argue that nobody knows whether or not birth rates will recover. They point out that the prognosis made by Eurostat shows considerably lower future fertility rates than the medium scenario of the United Nations.

Table 3: $\quad$ Total fertility rates, selected European countries, 1970-2035

\begin{tabular}{lccc}
\hline & $\mathbf{1 9 7 0 - 1 9 7 5}$ & $\mathbf{2 0 0 0 - 2 0 0 5}$ & $\mathbf{2 0 3 0 - 2 0 3 5}$ \\
\hline Norway & 2.25 & 1.80 & 1.85 \\
Germany & 1.64 & 1.35 & 1.54 \\
Czech Republic & 2.19 & 1.19 & 1.72 \\
Italy & 2.35 & 1.26 & 1.59 \\
\hline
\end{tabular}

Source: United Nations (2009) World population prospects: The 2008 Revision Population Database. Medium variant.

Prospective rising total fertility rates do, however, not necessarily mean that more children will be born. The reason is that calculations are made on the basis of agespecific fertility rates of women in their "child-bearing years". Since most women are between 20 and 40 years old when they have children, the number of newborns will depend on the number of women in this age group. With the exception of Norway, where the number of women aged 20-40 is expected to be quite stable during the next 25 years, there will be a rather drastic reduction in the number of women in this age group in the other three countries: $25 \%$ in Germany and Italy; $27 \%$ in the Czech Republic (United Nations 2009). In fact, although fertility rates are expected to increase somewhat in Germany and Italy in the coming years, the actual number of births is expected to decline in these two countries, according to the prognosis.

The demographic developments described above are all observed on a macro level. For us as generational researchers, a key question is: what are the implications of population ageing for families on a micro level? As we will show, there is no simple answer to this question. 


\section{Macro shifts - micro changes?}

It is commonly assumed that population ageing has altered family structures and will change them even more in years to come. Indeed, it has been suggested that apocalyptic thinking has dominated the discourse on population ageing (Gee and Gutman 2000; Robertson 1990) and its consequences for families (Rosenthal 2000).

According to Wolf (1994) cited above, it is evident that demographic forces on a macro level underlie kin patterns on a micro level. But is it really as evident as he has claimed? In contrast to Wolf's argument, Dykstra and Komter (2006) have pointed out that if we want to describe family structures, we simply cannot rely on population statistics. One problem with making assumptions about kin availability based on population demographics, is that it is necessary to consider mortality and fertility patterns across several generations. Being part of a multigenerational family, for example, does not only depend upon individuals' own fertility behaviour, but also on those of their children, parents, grandparents, etc. Furthermore, demographic trends may have contradictory effects at the family level (Watkins, Menken, and Bongaarts 1987). For example, increased longevity alone may imply a higher likelihood of belonging to four- or five-generational structures, but a postponement of parenthood reduces the probability.

In the following sections we discuss in detail the two most common assumptions found in the literature: increased life expectancy alters families' generational structure and lower fertility means fewer children to care for frail parents.

\subsection{Longer lives - more generations?}

A number of authors have argued that we have witnessed generational extension, with more generations present, but with fewer family members in each generation. To describe such new family structures, Bengtson and colleagues introduced the concept of "the beanpole family" (Bengtson, Rosenthal, and Burton 1990). Knipscheer (1992) wrote about a process of verticalisation: family members have more vertical, intergenerational ties, but fewer horizontal, intra-generational connections. Recently, Jensen and colleagues (2004) have commented that today's young children have more grandparents than siblings.

Although it has been claimed that families with four or five generations are becoming more and more common (e.g., Bengtson, Rosenthal, and Burton 1990; Bengtson et al. 2003; Harper 2003; Véron, Pennec, and Légare 2007), the reality is that we do not know to what extent this conclusion is accurate, and for whom. In fact, according to Uhlenberg (1993), no estimate exists to back up the claim. In France and 
the Netherlands, microsimulation has been performed to assess changes in family structures (e.g., Pennec 1997; van Imhoff and Post 1998), but, as pointed out by Pennec (1997: 76), such efforts "give a hypothetical reconstruction of reality rather than an actual photograph." Based on calculations of German mortality and fertility data, Grünheid and Scharein (2011) conclude that one cannot state that four-generational structures become more common because of longer life expectancy. For most countries, we do not know how generational structures of families looked fifty years ago, nor do we know exactly what they look like today. Fifteen years ago, Uhlenberg (1995) wrote "Although it is not intrinsically difficult to collect information on kinship lineages, it is surprising how little data we have on this topic" (p.24). The same conclusion can be drawn today. Researchers studying generational patterns often cannot provide information requested by policy makers, planners and mass media. Recently, we were contacted by a journalist who had talked to a great-great-grandmother with 14 greatgreat grandchildren. He wondered how common it is to become a great-greatgrandparent in Norway today. The fact is that we do not know. Neither do we know how many young children are members of five-generational lineages. Here we face the complex issue of anchoring: whose generational contexts are we focusing on? Mapping generational structures of families involves important issues of sampling as well as questions about data sources and measurement.

\subsubsection{Mapping individuals' generational structures: Methodological challenges}

In some countries, it is possible to obtain information about persons' generational position from national registries covering the entire population. Norway has excellent registries, but only for individuals born after 1950. This means that newborns in 2010 can be linked to parents and grandparents, but probably not to great-grandparents, and certainly not to great-great-grandparents. People old enough to be great-grandparents or great-great-grandparents are not linked to their children, grandchildren etc. Given this situation, a combination of data sources is called for. A common approach is to ask survey respondents about direct ascendant and descendant kin. Here we encounter the issue of sampling. When attempting to describe generational structures, it is extremely important to be aware of the age range of the respondents, as it will influence our estimates considerably. Surveys hardly ever include the persons most likely to be part of families with four of more generations: the oldest old and the very youngest. We will not find many four-generational structures if we choose college students as our anchors. The reason is simple: they are usually too old to be great-grandchildren and too young to have produced a new generation. Similarly, the majority of newly retired individuals have lost their parents but are not yet great-grandparents. 
A second issue is that due to time constraints and the need to limit the length of questionnaires, hardly any survey has included questions about all living generations, ascending and descending. In several studies, information is restricted to one or two generations above and below the respondent. One example is the National Survey of Families and Households (NSFH) in the United States, which contains no information on great-grandchildren or great-grandparents. Exploring the prevalence of fourgeneration family lineages using NSFH data, Matthews and Sun (2006) were only able to classify $60 \%$ of the original sample. More seriously, classification was particularly difficult among the oldest respondents, who have a high probability of belonging to a four-generational structure. In a somewhat puzzling conclusion, the authors state that being part of a structure including four generations is least likely among the oldest (75 years and older).

Another example is the International Social Survey Program (ISSP), in which information about numbers of generations is restricted to adult generations and only two generations above and below the respondent. Using the ISSP data to describe generational structures is therefore treacherous, but Farkas and Hogan (1995) attempted to do so anyway. They were surprised to find that only a very small proportion of people aged 45 to 64 were part of structures with four generations (3\%). Since they only had data on adult generations, this may imply five generations (a possibility the authors recognise).

Both studies mentioned above underestimate the prevalence of multigenerational structures. On the other hand, using data from the U.S. Health and Retirement Study (HRS) will overestimate the prevalence, as illustrated in work by Soldo and Hill (1995). Again, we see the significance of anchors. The first wave of the Health and Retirement Study, the basis for Soldo and Hill's analyses, includes people born 1931-1941, which means that they were 51-61 years of age when the data were collected. People in their fifties are quite likely to be part of four-generational structures, as they may still have at least one parent living, while most of their children are old enough to have produced grandchildren. According to Harper (2003), who refers to Soldo and Hill, more than half of the respondents are part of family structures with at least four generations. However, this is only partially true, since Harper's figures are based on married respondents only. Soldo and Hill have separate data on unmarried individuals. Among these respondents, less than a third has direct ascendant or descendant ties to at least three generations. As we know, having children (and grandchildren) is strongly related to current and former marital status, at least for the cohorts included in the study.

The Survey of Health and Retirement in Europe (SHARE) includes questions that make it possible to map the number of generations, but the sample is limited to persons aged 50 and over. It is interesting however, to note differences between the countries. While one fourth of Swedes aged 50 or older are part of structures with four 
generations, the same is the case for only $11 \%$ in Italy and Greece (Kohli, Künemund, and Lüdicke 2005). The timing of births and deaths determines the prevalence of multigenerational structures. In a comparison of Hungary and the Netherlands, Knipscheer and colleagues (2000) found that more Hungarians were great-grandparents, even though the Dutch have a higher life expectancy. Having children at an earlier age in at least two generations has produced "accelerated generational turn-over" in Hungary.

Norwegian data from the life-course, ageing, generations and gender study (NorLAG/LOGG) $^{3}$ show that overall, $20 \%$ of the respondents are part of structures including four generations (Figure 1). Analyses of data from the Generations and Gender Survey reveal similar figures for France and Bulgaria (Puur et al. 2011). There are, however, sharp differences between age groups. Being part of a structure with at least four generations is most likely among Norwegian respondents in their thirties and among 75-79 year-olds (both around 30\%) and least likely among the youngest, 18-24 year olds and middle-aged people aged 45 to 49 (10-11\%).

Although the NorLAG/LOGG data set provides quite a good picture of generational constellations among Norwegians, it also has shortcomings. Some of the limitations, both with regard to sampling and survey content, reflect the fact that the study is part of the Generations and Gender Survey of the United Nations (GGS) (United Nations 2007a). Thus the sample does not cover the youngest (0-17) or the oldest (80+). Another limitation is that we do not have information about all possible generations for all respondents. For example in Norway, questions about grandparents were only asked to respondents younger than 47, even though the first wave of NorLAG included grandchildren above that age, the oldest one being a granddaughter aged 56. Similarly questions about great-grandparents were only posed to respondents younger than 27. No information was obtained about great-great-grandchildren.

\footnotetext{
${ }^{3}$ The Norwegian study NorLAG/LOGG represents a merger of the United Nations initiated Generations and Gender Survey (GGS) and the second wave of the Norwegian Life-course, Ageing and Generation Study (NorLAG). Data collection took place in $2007-2008$, based on a nationally representative sample of persons aged 18-79 $(\mathrm{N}=14,700,61 \%$ response rate). For more information about NorLAG/LOGG, see http://norlag.nova.no.
} 
Figure 1: Number of living generations by age group. NorLAG/LOGG 2007-2008 (\%)

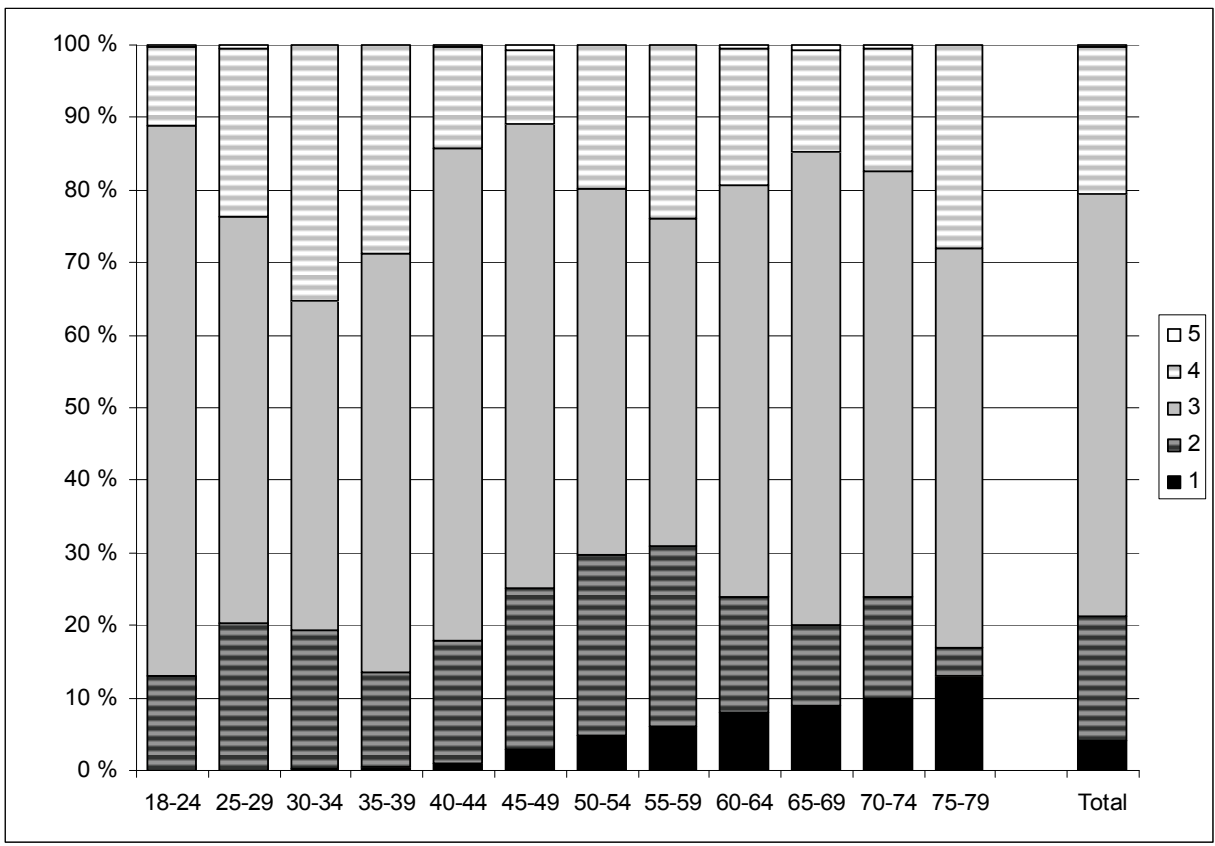

In the European OASIS study (Old age and autonomy: the role of service systems and intergenerational family solidarity) (Lowenstein et al. 2002), the survey only included questions about two generations above and below the respondent. In order to compensate for this limitation, an honest attempt was made in the Norwegian component by simply asking the respondents how many generations were present in their family. This may seem like a straight-forward question (as it initially also did to the researchers involved, including the first author of the present paper), but as it turned out, there were no straightforward answers. Some respondents only included the generations in the nuclear family; others restricted their answer to the household. Individuals without parents and children tended to state that they were part of structures with more than one generation, probably including nieces, nephews and their children, or partner's kin, in their generational structure. 


\subsubsection{Generational structures: Who is the anchor?}

One of the reasons why mapping individuals' generational structures is complex, is that western families are based on what is called a bilineal descent, in which kin connections are traced through both maternal and paternal lines. Anthropologists studying kinship patterns in traditional societies often have an easier task, as unilineal systems are common, meaning that only one line matters. To illustrate some of the complexities facing scholars with an interest in generational structures in western societies, we use some simple, concrete examples of connections to direct descendants (Figure 2) and ascendants (Figure 3).

Karen, who is 87 years old, is part of a four-generational structure, as she has children, grandchildren and great-grandchildren. Both her oldest and youngest child also belong to structures including four generations (having children, grandchildren and a parent still living). Her middle child Janet, being childless, is without direct descendants, and consequently is in a structure consisting of only two generations. Whether or not Janet regards herself as part of a four- or a two-generational family, is another question. Although she does not have children and grandchildren herself, she might consider her nieces and nephews and their children as part of her family structure. And what about Eric, Karen's second oldest grandchild? He does not have children yet, but his brother and sister do, making his parents grandparents and his grandmother a great-grandmother. Although his generational structure consists of three generations, he might consider himself as belonging to a four-generational family.

Theo, aged 3, is one of Karen's great-grandchildren. He is, as Figure 2 shows, part of Karen's four-generational structure. But when we look at his (Theo's) structure (Figure 3), we discover that the various lineages to which he belongs have different depths. His lineage on his father Tom's paternal side consists of only three generations, on his father's maternal side, four generations, whereas the lineage on his mother Emma's paternal side consists of four generations, and his mother's maternal side, five generations. 
Figure 2: An example of a generational structure seen from the top: The case of Karen

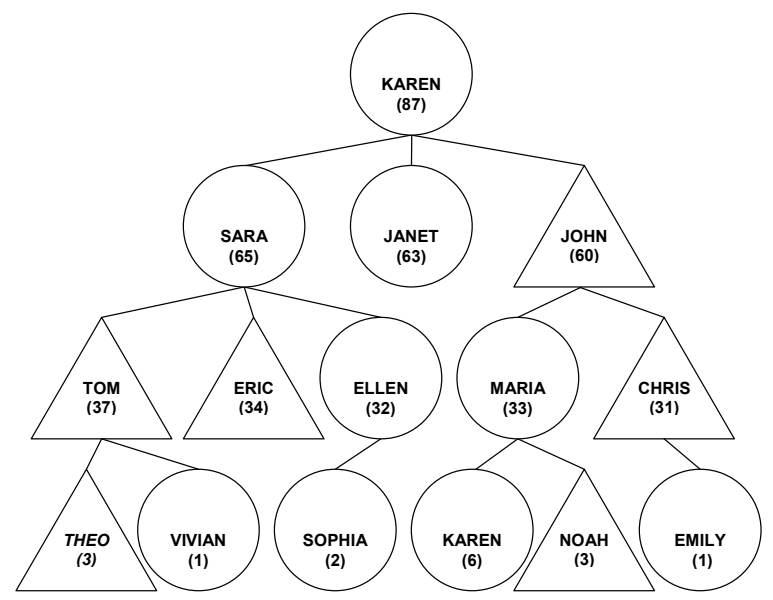

Figure 3: An example of a generational structure seen from the bottom: The case of Theo

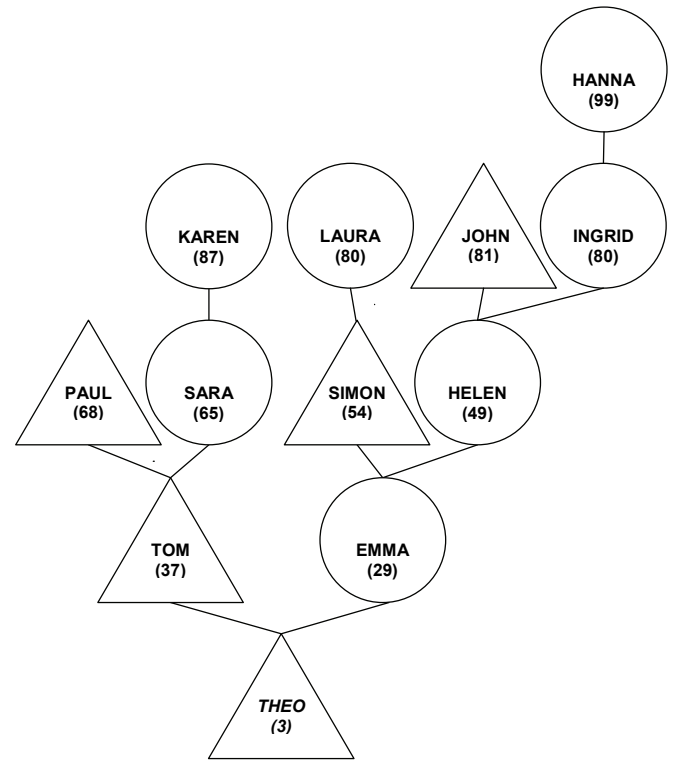


The figures above illustrate the impossible task of counting families or regarding intergenerational families as units of analysis. Members of one individual's generational structure are also part of other structures, which means that families have no clear boundaries. Karen does, as we saw in Figure 2, have a constellation of four generations, but her middle daughter has only two. Theo belongs to Karen's fourgenerational structure, but he also has a lineage including three and one consisting of five generations present in his structure (Figure 3).

Among the surveys mentioned in section 3.1.1, mapping Karen's generational structure correctly would only have been possible with the SHARE study. In the others, she would either be too old to be part of the study sample, or she would only have been asked about children and grandchildren, not great-grandchildren. Would the fivegenerational structure to which Theo belongs be discovered in any of the surveys (Figure 3)? Theo is too young for all the studies mentioned. His mother, Emma, is too young to have been included in SHARE and HRS. Mapping all her five generations would not be possible with any of the other surveys either, as none includes questions about great-grandparents. Helen (Emma's mother and Theo's maternal grandmother) is 49 and thus too young for SHARE and HRS, and presumably too old to have grandparents still living, according to the restrictions in the NorLAG/LOGG questionnaire. In contrast, it would be possible to map her structure with the GGS, the NSFH or the OASIS study. GGS and SHARE have questions about greatgrandchildren, but mapping Ingrid's (Helen's mother) generational structure correctly would only be possible with SHARE, since she is too old to be part of GGS. Ingrid's mother Hanna is also too old for many survey samples, and none of the studies including persons over 80 has questions about great-great-grandchildren.

\subsubsection{Multigenerational structures: Summing up}

As we have illustrated, knowledge of how demographic changes have altered the generational structures of families is quite incomplete. It is not known how common four- or five-generational families were fifty years ago, how common they are today, or their possible prevalence in years to come. According to Uhlenberg (1995), there is nothing intrinsically difficult in collecting information about ascendants and descendants. However, the examples presented show that this is indeed a tricky task. Generational structures are complex, often including lineages of various depths. Thus being part of a three-generational lineage does not exclude the possibility of also belonging to lineages including four, even five, generations.

How common are four-generational structures in a given society? This is an unanswerable question. The reason is that multigenerational families have no clear 
boundaries. Consequently they cannot be considered as the unit of analysis because there is no way to obtain a sample of a general population. Studies of three-generational families (e.g., Bengtson, Silverstein, and Giarrusso 1995 (Southern California); Hill et al. 1970 (Minnesota); Rossi and Rossi 1990 (Boston area)) may give the impression that these families can be delineated and counted, but we need to be aware that participants in such studies can have generations present in their structures in addition to those included in the original study samples (which were restricted to three generations). This is important because wider generational contexts may be significant for the relationships studied. In order to pose an answerable question about generational structures, it is crucial to specify anchors by age/cohort and gender, and to provide some ground rules for how to count. If our research interest is four- and fivegenerational structures, we need to count the number of individuals who are members of at least one such structure. This gives an estimate of how common it is for men and women to be embedded in given generational structures, but it does not say how common these structures are in a particular population. In the case of Norway, figure 1 shows that $20 \%$ are members of four-generational structures, but this finding cannot be translated into the statement that $20 \%$ of Norwegian families consist of four generations. It is also important to recognise that generational constellations do not last forever. Four- and five-generational structures, in particular, are often ephemeral (Theo's great-great-grandmother is 99 years old). Structures consisting of three generations are more common, and many are characterised by long duration.

So far, we have concentrated on implications of population ageing for multigenerational structures. We now turn to the issue of decreasing fertility and the supply of adult children who can provide care for frail parents.

\subsection{Lower fertility - fewer children to care for old parents?}

There is no doubt that population ageing may have great macro level consequences, with more people in ages when care needs are relatively common and fewer people in care-providing ages (as shown for example in Uhlenberg and Cheuk 2008). What is more debateable is whether or not the consequences at the population level will be mirrored at the family level. Nonetheless, a number of publications on family care build on the premise that fertility decline during the last decades has lead to fewer children in the family, and thus fewer potential care providers for frail parents in the future (e.g., Clarke 1995; Daatland and Herlofson 2003; European Foundation for the Improvement of Living and Working Conditions 1995; Monk 1983; Morrison 1990;

Pickard 2002; Tennstedt, Crawford, and McKinley 1992). As we will show below, the premise has its problems. 


\subsubsection{Women's number of children versus mothers' number of children}

Decreasing fertility rates over recent decades have received a considerable amount of attention, in particular among demographers. In gerontology, the interest in fertility is mostly motivated by a concern for parent care in years to come. It is, however, important to keep in mind that standard measures of fertility are woman-based and therefore not perfectly indicative of the number of children in families with children. Bytheway (1974) has warned us of the "statistical trap associated with family size." He examined the number of children among married mothers aged 50-54 in England and Wales in 1961, and found that whereas 34\% had one child, only $14 \%$ of these women's children were only children. Langford (1982) did a similar calculation, and demonstrated that among women who were married in the period 1930-40, the mean number of children was 2.5 , but the children of these women grew up in families with more than four children on average. Perhaps the most influential demographic discussion of this issue is a publication by Preston (1976) entitled "Family sizes of children and family sizes of women." Although an appealing title, it may not be obvious to all what Preston meant by family size. His message is clear, however: "if half of a group of women have four children and half have none, the average size for a woman will be two, but for a child it will be twice as large" (p. 105). To sum up: although the decline in fertility means a decrease in average number of children per woman, it does not necessarily mean that the average number of children among mothers is dramatically lower. A critical factor to consider is patterns of childlessness.

Mapping trends in childlessness is, however, not an easy task. As Dykstra and Hagestad (2007a) note, the childless have to a large extent been rendered invisible in the research literature. Demographers have been considerably more interested in fertility than infertility, and researchers with an interest in families and intergenerational ties have overlooked the rather large proportion of persons who do not have children. Existing statistics on childlessness have gaps, show inconsistencies, and typically only include women (Dykstra 2009). Until recently such an important demographic indicator as childlessness has not been available in a number of countries. Several authors have used Germany as an example and pointed out that the exact proportion of childless among German women is unknown, what exist are estimates (Dorbritz 2008; Frejka 2008; Kreyenfeld et al. 2010).

Table 4 includes a childlessness rate of $29 \%$ for the West German 1966 birth cohort as estimated by Dorbritz (2008). This figure is quite similar to the one presented by Tanturri and Mencarini (2008) for the 1960 birth cohort (28\% for West Germany, based on Eurostat data). As the table shows, there are different trends in cohort fertility and childlessness in the four countries (Norway, West Germany, The Czech Republic, and Italy). Small cohort changes are observed for the Czech Republic. The proportion childless remained quite stable and the completed average number of children per 
women fell by 0.2 from the 1935 to the 1965 birth cohort. Norway witnessed a small increase in childlessness, and a decline in cohort fertility of 0.4 . In both Norway and the Czech Republic, we see that the reduction in the average number of children per woman and in the average number of children per mother were the same. In Italy, there was a rather sharp decline in cohort fertility (from 2.3 to 1.5 ) and a considerable increase in childlessness (from $15 \%$ to $24 \%$ ). Still, changes in women's and mothers' number of children were more or less identical (-0.8 vs. -0.7$)$. Also West Germany experienced a clear change in cohort fertility (-0.7), but the most remarkable change has been the increase in childlessness, from less than $10 \%$ among women belonging to the 1935birth cohort to almost 30\% among women born around the mid-1960s (Dorbritz 2008; Frejka 2008). Whereas the average number of children per woman fell with 0.7 , the reduction was less pronounced for the average number of children among mothers (-.03). Devolder (2005) sums it up nicely: the rise in childlessness may hide a stability in the fertility of mothers. Germany is a case in point.

Table 4: Total cohort fertility rate, proportion childless women, and changes in average number of children among women and mothers for selected European countries, 1935- and 1965-cohort

\begin{tabular}{lcccccc}
\hline & \multicolumn{2}{c}{1935 cohort } & \multicolumn{2}{c}{1965 cohort } & \multicolumn{2}{c}{ Cohort change (1935-1965) } \\
\cline { 2 - 7 } & $\begin{array}{c}\text { cohort } \\
\text { fertility } \\
\text { rate }\end{array}$ & $\begin{array}{c}\% \\
\text { childless } \\
\text { women }\end{array}$ & $\begin{array}{c}\text { cohort } \\
\text { fertility } \\
\text { rate }\end{array}$ & $\begin{array}{c}\text { \% } \\
\text { childless } \\
\text { women }\end{array}$ & $\begin{array}{c}\text { women's } \\
\text { average number } \\
\text { of children }\end{array}$ & $\begin{array}{c}\text { mothers } \\
\text { average number } \\
\text { of children }\end{array}$ \\
\hline Norway $^{1}$ & 2.4 & 10 & 2.0 & 12 & -0.4 & -0.4 \\
Germany $^{2}$ & 2.2 & 9 & 1.5 & 29 & -0.7 & -0.3 \\
Czech Republic $^{3}$ & 2.1 & 7 & 1.9 & 8 & -0.2 & -0.2 \\
Italy $^{3}$ & 2.3 & 15 & 1.5 & 24 & -0.8 & -0.7 \\
\hline
\end{tabular}

${ }^{1}$ Norway: 1964 birth cohort. Source: SSB: Barnetallfordeling etter alder og kohort, (http://www.ssb.no/fodte/arkiv/tab-2006-04-20-08.html).

${ }^{2}$ Western Germany: estimate for the 1966-cohort.

Sources: Sardon (2006) for the 1935-birth cohort, Dorbritz (2008) for the 1966 birth cohort.

${ }^{3}$ Czech Republic and Italy: Sources: Sardon (2006) for the 1935-birth cohort and Frejka (2008) for the 1965-birth cohort.

\subsection{2 "The parent support ratio": A population level indicator with a family level label}

A ratio has been calculated to "assess the demands on families to provide support for their oldest-old members" (United Nations 2002:21). In English the measure is called 
the parent support ratio. Other languages also point to the family in naming the indicator: Elternunterstützungsverhältnis in German, la percentuale di sostegno ai genitori in Italian, and familieomsorgskoeffisienten in Norwegian (the direct translation of the latter is "the family care ratio"). An important objection to this terminology is that the indicator does not reflect the situation at the family level. The people in the numerator and in the denominator are not related by kin. As a matter of fact, the supposed "parents" may not even have children, and the "children" may not have parents living, since the ratio only indicates the number of persons $80+($ or $85+$ ) per 100 persons aged 50-64 in the population. Kinsella and his colleagues (Kinsella and Taeuber 1993; Kinsella and Velkoff 2001), the architects behind the ratio, are well aware of the measure's problematic aspects. In fact, they do point out that the ratio "is only a rough indication of need for family support over time" (Kinsella and Velkoff 2001:79). Given such concerns, why not call it something else? "Old people support ratio" would be a more valid term, but here a problem is that an "elderly support ratio" is already in use. This indicator, which is sometimes also called the "elderly dependency ratio" or "old age dependency ratio," is defined by the number of people 65+ (i.e., of retirement ages) per 100 persons in working ages (15 to 64 or 20-64) (Kinsella and Velkoff 2001; United Nations 2002). Table 5 shows the "parent support ratio" for the four selected countries. As we see, the figure varies considerably across the countries (from 13 in the Czech Republic to 27 in Norway) and the change from 2000 to 2030 is expected to be considerably greater for Germany, Italy, and the Czech Republic than for Norway:

Table 5: "Parent support ratio" (number of people aged 80+ per 100 people aged 50-64), selected European countries, 2000-2030

\begin{tabular}{lcc}
\hline & $\mathbf{2 0 0 0}$ & $\mathbf{2 0 3 0}$ \\
\hline Norway & 27 & 35 \\
Germany & 19 & 36 \\
Czech Republic & 13 & 30 \\
Italy & 22 & 37 \\
\hline
\end{tabular}

Source: Kinsella, K. and Velkoff, V.A. (2001). An aging world: 2001.

If the task is to assess demands on adult children to provide support for their parents, as indicated in a UN report (United Nations 2002), a more realistic "parent support ratio" is needed. A first step could be to calculate the number of 50-64 year olds who actually have parents living and how many of these parents are aged $80+$ (or 85+). In doing so, it is important to keep in mind that individuals do not march into family 
generations by age and cohort (Hagestad 1981, 2001). In fact, analysis of the Norwegian NorLAG/LOGG data reveals that more than $50 \%$ of the respondents aged 50-64 have lost both parents. Canadian data show a similar figure (Rosenthal, MartinMatthews, and Matthews 1996). A more proper procedure in calculating a "parent support ratio" might be to consider parental needs. The existing indicator seems to build on the assumption that after reaching a certain age, parents are in need of assistance by default, or that being between 50 and 64 means having parents who require help. Such assumptions are questionable. Only $20 \%$ of Norwegians aged 50-64 in the NorLAG/LOGG study report having parents in need of assistance. Furthermore, less than half of the respondents' mothers and only about one third of the fathers aged 80 years and older require help with daily chores. If we restrict the analysis to parents 85 years and older, we obviously find more in need of help, but still, $40 \%$ of the mothers and around $50 \%$ of the fathers manage everyday life without assistance. Matters become even more complex when we look at the actual age of respondents who report having parents in need of help. In the Norwegian data, we find that almost 6 out of 10 adult children with parents needing assistance were either younger than 50 (as many as $54 \%$ ) or older than $64(4 \%)$. Among the respondents' mothers and fathers in need of help, around $50 \%$ were younger than 80 .

Finally, the indicator appears to be built on the assumption that siblings contribute equally in care provision for old parents. Below, we will demonstrate that this is a questionable premise.

\subsubsection{More children - more care?}

It is important to recognise that although the decline in fertility may have implications for the number of siblings, it does not necessarily mean a reduction in the number of adult children who will be ready to care for older parents in need of help. Finch and Mason (1993) have described in detail how family responsibilities are negotiated over time, and how some children in the family end up committing themselves to taking care of parents, while others do not. Earlier research has demonstrated, perhaps contrary to common belief, that having fewer siblings increases the probability of providing help (Spitze and Logan 1991; Stuifbergen et al. 2008; Brandt, Haberkern, and Szydlik 2009) and keeping in touch with parents (van Gaalen, Dykstra, and Flap 2008). Having many siblings may make it easier to avoid care responsibility by passing it on to brothers, and in particular to sisters. Analysis of the Norwegian LOGG/NorLAG data shows that help rates (regular practical help and/or personal care) among only children with parents in need of help are higher than among those with siblings. $48 \%$ of only children had been involved in provision of regular help/care to parents during the last 12 months, 
compared to $33 \%$ of those with 3 or more siblings. Here it is necessary to be aware of what Freedman and colleagues (1991) call the "mathematics of perspective". Are we studying help rates among the providers, in this case the adult children, or among the recipients, the parents? It is important to remember the asymmetry problem: the proportion of the former is not the same as the proportion of the latter. The reason is simply differences in number of "eligibles". Research that has shown how the probability of being involved in parental care declines with number of siblings, is not in conflict with studies concluding that amount of help received by parents increases with the number of children (e.g., Eggebeen 1992; De Jong Gierveld and Dykstra 2006). Uhlenberg (1993) suggests that the benefits from each additional child beyond the second or third are minimal, but a critical distinction is that between having only one and having two or more children. However, when Ogg and Renault (2006) analysed parents' reports of help receipt (parents 75+ with children born 1945-1954), having one child or having two or more did not make a significant difference. Clearly, this research area still poses unanswered questions regarding the impact of number of children on support to parents.

When studying the availability of adult children to care for old parents, the number of children born to a woman is less important than the actual number of surviving offspring when parents become old and frail. Child mortality typically refers to the death of "chronological children": infants and children under the age of five. But what about mortality among offspring at any age? A possible implication of longer lives may be an increase in the risk of losing an adult child, in particular an adult son, and in particular for old mothers. Little is known about number of surviving children among old men and women in different birth cohorts (Murphy, Martikainen, and Pennec 2006), and outliving one's children is an issue which has only very briefly been discussed in the research literature (Dykstra 2009; Dykstra and Hagestad 2007b).

\subsubsection{The future of parent care: Summing up}

We are in agreement with Rosenthal (2000) who states: "It is fair to say that alarm calls about the shrinking supply of children are an overstatement - if not a distortion of reality" (p. 51). Agree and Glaser (2009) have recently pointed out that policymakers tend to focus heavily on decreasing fertility rates. Declining fertility rates, however, do not necessarily threaten future care for frail parents. One reason is that a lower average number of children per woman may not mean dramatically fewer children among mothers, as we have illustrated in the case of Germany. Not only fertility rates, but also childlessness must be considered when discussing consequences of fertility change for future care. Given recent developments in childlessness, it is essential not to equate 
elder care with parent care as a growing proportion of future cohorts of older people will not be parents.

If the purpose is to examine potential parent care, the "parent support" ratio has limited utility since it is calculated on the basis of macro level statistics, although framed in family level language. Furthermore, the indicator seems to build implicitly on an assumption that sibship size matters, which we have shown is problematic. It is necessary to recognise that having fewer siblings may increase the propensity to provide care to parents, rather than the contrary. To our knowledge, no study so far has systematically examined the correlation between number of offspring and the total amount of help received by old parents from their children.

Discussing whether or not the proportion of older persons needing care will increase in the future is beyond the scope of this paper. The evidence so far regarding disability rates is mixed (e.g., Jacobzone et al. 1999; OECD 2007; Sanderson and Scherbov 2010), but there are indications that late-life disability is decreasing because of factors such as increased educational levels and growing use of new technology (e.g., Batljan, Lagergren, and Thorslund 2009; Christensen et al. 2009; Freedman et al. 2004; Schoeni, Freedman, and Martin 2008). No matter what the disability rates are in the future, discussions of care and support across generations raise complex issues that must be addressed on both the macro level of population and the micro level of family.

\section{The centrality of gender in generational research}

The attentive reader most likely wonders about the issue of gender in the above discussion, in particular because the Generations and Gender Programme, which we have referred to several times, builds on the premise that gender and generations must be studied together. It is well-known that due to gender differences in life expectancy, many of today's ageing societies have two to three times as many women as men among the oldest old. Therefore, it is common practice that reports on population ageing not only include numbers of old persons (usually 65+) and children (under 15), but also overviews of sex ratios in the older population for various countries (e.g., Kinsella and Velkoff 2001; United Nations 2007b). As Table 6 shows, there are striking differences across European societies with regard to the presence of men aged 75 and over in the population. In addition to our four selected countries, the table includes Estonia and Russia (both are part of the Generations and Gender Programme). The reason for including these two countries is the exceptional imbalance between men and women in the older population. In Norway and Italy, there are 59 and 52 men, respectively, per 100 women in the older population. The corresponding figures for 
Herlofson \& Hagestad: Population and family structures in ageing societies

Germany and the Czech Republic are 49 and 51. In quite sharp contrast, Russia and Estonia have ratios of 34 and 37.

Table 6: Sex ratio $75+$ and number of women/men $75+$ per 100 children under 15 (2005). Selected countries

\begin{tabular}{lccc}
\hline & Sex ratios 75+ & Women 75+/children & Men 75+/children \\
\hline Norway & .59 & 24 & 14 \\
Germany & .49 & 37 & 18 \\
Czech Republic & .51 & 28 & 14 \\
Italy & .52 & 41 & 24 \\
Estonia & .37 & 33 & 12 \\
Russia & .34 & 26 & 9 \\
\hline
\end{tabular}

Source: United Nations (2009) World population prospects: The 2008 Revision Population Database.

To our knowledge, no one has so far combined sex ratios in the older population and number of old persons per 100 children under 15 (see Hagestad (2008a) for an exception). When we look at the second and third column in Table 6, it is important to take into account the combined impact of recent trends in fertility and gender differences in longevity. For example, sex ratios $(75+)$ in Norway and Italy are fairly similar, but because of different fertility patters in recent years, young Italians have far more old women and men potentially available compared to young Norwegians. Our main purpose in combining sex ratios and old/young ratios is to illustrate how children in ageing societies grow up surrounded by considerably more old women than old men. In Norway, there are 14 men and 24 women aged $75+$ per 100 children under 15 . The ratios in Russia are 9 and 26 respectively, meaning that Russian children have almost three times as many old women as old men potentially available.

At the family level, studies of grandparenthood have documented the centrality of grandmothers, in particular maternal grandmothers (e.g., Dubas 2001; Eisenberg 1988; Kennedy 1990; Matthews and Sprey 1985). Explanations commonly include discussions of women's kinkeeping role and the centrality of the mother-daughter bond. An often overlooked fact is simple demography: mother's mother is generally the youngest, and is therefore the grandparent sharing most years, on average, with grandchildren (Hagestad 1985, 2006; Keck and Saraceno 2008; Spitze and Ward 1998). In a recent study of Norwegian 11- 12-year olds and their grandparents (NorGRAND), we found that $87 \%$ of the children had maternal grandmother and $66 \%$ had paternal grandfather living. Analysing the birth year of the respondents' parents revealed that mothers' mothers were on average born 7 years later than fathers' fathers. Thus, fewer maternal grandmothers were already deceased at the time of the survey, and among 
those still living, maternal grandmothers were on average almost four and a half years younger then paternal grandfathers. The combination of gender differences in mortality and in fertility patterns has even greater consequences for the availability of maternal and paternal grandmothers and grandfathers to adult grandchildren. The NorLAG/LOGG study shows that among Norwegians in their thirties, around $40 \%$ had at least one grandparent still living. Among these adult grandchildren, $62 \%$ still had their maternal grandmother and only $15 \%$ had their paternal grandfather.

The contrasts discussed above are obviously also reflected in the relationship between adult children and parents. When we look at NorLAG/LOGG respondents aged 50 and older who have at least one of their parent still living, almost 9 out of 10 have mothers; only around one third have fathers. If we restrict the analysis to respondents 60 and above, having a surviving parent means almost exclusively having mothers ( $92 \%$ versus $17 \%$ ). As a consequence, many more mothers and daughters compared to fathers and sons share the experience of ageing and growing old together, a fact that is often overlooked in research on intergenerational relations.

Another result of gender differences in mortality and fertility patterns is the gender imbalance in generational structures. Yet, we have limited knowledge about how common it is it to have two, or even three, older generations consisting of women only. After recent media attention focused on great-great grandparents in Norway, the second author has been contacted by a host of individuals providing information on their five generation families. So far, there is no great-great grandfather on the list. In order to study men and women in multigenerational structures, not only must the gender of the anchor be specified, but also the gender of members in ascending and descending generations. To our knowledge, this has not been common practice in research. Typically, respondents are only asked about the number, and not the gender, of (great, great-great) grandparents still living.

The issue of gender is also highly central in discussions of dependency ratios and their possible implications for family generations. Here, considerations of gender contrasts not only in mortality, but also in morbidity are important. The reality expressed in the proverb, women are sicker, men die quicker, or as a recent Norwegian book title states it: women suffer, men die (Schei and Bakketeig 2007), has been of longstanding interest to scholars (e.g., Doblhammer and Hoffmann 2010; Oksuzyan et al. 2008). Discussions of filial obligation usually are about adult children's responsibility to "generic" parents in need of care, but reality is that typically, these parents are mothers, not fathers. When we analyse panel data from the two waves in NorLAG/LOGG (data collections in 2002/2003 and 2007/2008), we find that among old parents who, according to their adult children, needed help at both points, $84 \%$ are mothers. It is also important to remember that whereas most old men live with their partner, old women live alone. Current Norwegian statistics show that $59 \%$ of men over 
80 are married compared to only $19 \%$ of women (Hagestad and Herlofson 2010). As a consequence, old men can often call upon their partner for care; for old women this is typically not an option.

\section{Some overlooked and underexplored issues}

In closing, we would like to briefly outline three issues that still need new attention from researchers: "generational solos", "the postponement revolution", and children's kin structures.

\section{Generational solos and their kin}

In intergenerational research, the focus on a presumed growth in multigenerational families has made researchers overlook the substantial number of generational solos: individuals without any direct ascendant or descendant generational links. Reality is that in some countries they represent a considerable group. SHARE data show that $12 \%$ of the respondents (aged 50+) in Germany, Austria and Italy are solo individuals. In Italy, they even outnumber those belonging to structures of four and five generations (Kohli, Künemund, and Lüdicke 2005). Analysis of intergenerational family constellations based on data from the Generations and Gender Survey, reveal that the share of generational solos among the 60-79 year olds varies from 5\% in Bulgaria to $18 \%$ in Germany (Puur et al. 2011). Among the participants in the Berlin Aging Study (aged 70+), as many as almost one quarter were without direct generational links (Wagner, Schütze, and Lang 1999). A number of studies on old age do not include individuals who are not embedded in intergenerational chains, because the focus is either on elderly parents or on middle-aged children. Solos are by definition childless. Recently, several publications on childlessness in old age have emerged (e.g., Connidis 2010; Dykstra 2009; Dykstra and Hagestad 2007a; Kohli and Albertini 2009; Kreager and Schröder-Butterfill 2004; Wenger 2001). However, there are still gaps in this literature, in particular regarding childless men. As already mentioned, several countries have incomplete or missing data on childlessness, especially for men. Consequently, there is often no way to know whether or not individuals without offspring are underrepresented in study samples. A recent overview of social networks among old people with and without children shows that childless older adults tend to have stronger ties to siblings, cousins, nieces and nephews compared to individuals who are parents (Wenger et al. 2007). In several countries, one-child families are becoming more common (e.g., Frejka 2008). Who will unpartnered childless individuals without siblings, cousins, nieces and nephews turn to in their future old age? 


\section{Potential consequences of the postponement revolution}

It is a well-known fact that women, on average, have their first child later in life today than they did a few decades ago (e.g., Billari 2005; Frejka and Sardon 2006). Still, a recurrent, unresolved issue is the long-term effect of postponed childbearing for generational structures. Dutch and German data suggest that the proportion of people in four-generational structures will drop in the near future because of delayed entry into parenthood (Dykstra 2003; Grünheid and Scharein 2011). Murphy and Grundy (2003) demonstrate how the duration of ties between a mother and her children depend on the mother's age at birth. They compare children of women in the lower and upper deciles in age at childbearing and show that at age $60,74 \%$ of the former will have their mother still living, compared to only $9 \%$ of the latter. Thus, parenthood postponement may shorten the duration of parent-child ties in the future, if it is not counteracted by a further increase in longevity. The future of human longevity has received considerable attention, with perspectives ranging from a fairly "pessimistic" (e.g., Carnes and Olshansky 2007; Olshansky and Carnes 2009) to an "optimistic view" (e.g., Oeppen and Vaupel 2002). What is clear is that both fertility and mortality trends are highly influenced by educational level. Therefore, scholars have started to develop educationspecific population projections (e.g., Lutz et al. 2007; Samir et al. 2010). Educational level is also of relevance for studies of generational structures at the micro level. To what extent increased educational level "compensates" for postponed childbearing through associated increased longevity, is still an open question.

\section{The generational structures of children}

There is considerably more knowledge about generational contexts of middle-aged and old individuals than is the case for children and youth. One reason is that it is more difficult to map from the bottom than from the top because of bilinear descent, as we have shown earlier (3.1.2). Another reason is the somewhat myopic focus on the immediate nuclear family among scholars interested in children and adolescents. As Keck and Saraceno (2008) have suggested, there seems to be an assumption that crossgenerational relations matter less for the young than for the old, with the exception of the tie between young children and their parents. A third reason is the common assumption that population ageing primarily alters the social landscapes of middle-aged and old persons. The fact is, however, that children's kin networks have been more affected by population ageing than is the case for the old. For example, it is reasonable to assume that there were just as many grandparents among individuals who survived to old age a century ago as is the case today. In sharp contrast, children today are about seven times more likely to have all four grandparents living than was the case in 1900 (Uhlenberg 1996; Hagestad and Uhlenberg 2007). Recent discussions of widening 
inequalities among children (Esping-Andersen and Sarasa 2002; Sørensen 2005) make it clear that we must map children's kin resources and seek to understand how intergenerational ties, especially to grandparents, contribute to children's social and cultural capital (Hagestad 2008b). Comprehensive studies of the availability and contributions of grandparents to boys and girls are needed, especially in countries with strongly imbalanced sex ratios in the older population.

\section{Moving from macro to micro - summing up}

In order to understand the needs and resources of citizens in ageing societies, two distinct kinds of data are needed: information on macro level population patterns and micro level data on family structures surrounding individuals in different stages of life. Traditional demography has provided essential tools for describing population structures and dynamics. On a micro level, family research has produced rich accounts of intergenerational ties in ageing societies. As stated at the outset, researchers and policy makers need to be aware of the possibility that the two types of data may present divergent pictures. The main purpose of this paper has been to identify important and thorny issues facing researcher who attempt to take on the somewhat intimidating task of bridging the two levels. We hope that this article contributes to ongoing discussions, inspires new endeavours, and stimulates further explorations of how population ageing shapes family networks of men and women in different age groups.

\section{Acknowledgements}

The work on this article was made possible through support from the European Union's Seventh Framework Programme [FP7/2007-2011]) under grant agreement $n^{\circ} 217523$ for the project MULTILINKS (How demographic changes shape intergenerational solidarity, well-being, and social integration: A multilinks framework) and from The Research Council of Norway for The Norwegian Life-course, Ageing and Generation Study. We thank the two anonymous reviewers of Demographic Research, as well as guest editor Pearl Dykstra, for their useful comments and suggestions. 


\section{References}

Agree, E.M. and Glaser, K. (2009). Demography of informal caregiving. In: Uhlenberg, P. (ed.). International Handbook on Population Aging. Springer: 647-668.

Batljan, I., Lagergren, M., and Thorslund, M. (2009). Population ageing in Sweden: The effect of change in educational composition on the future number of older people suffering severe ill-health. European Journal of Ageing 6(3): 201-211. doi:10.1007/s10433-009-0120-1.

Bengtson, V.L., Lowenstein, A., Putney, N.M., and Gans, D. (2003). Global aging and the challenge to families. In: Bengtson, V.L. and Lowenstein, A. (eds.). Global Aging and challenges to families. New York: Aldine de Gruyter: 1-24.

Bengtson, V.L., Rosenthal, C., and Burton, L. (1990). Families and aging: Diversity and heterogeneity. In: Binstock, R.H. and George, L.K. (eds.). The handbook of aging and the social sciences. New York: Academic Press: 263-287.

Bengtson, V.L., Silverstein, M., and Giarrusso, R. (1995). The Longitudinal Study of Generations. In: Maddox, G. (ed.). Encyclopedia of aging. New York: Springer.

Billari, F. (2005). Partnership, childbearing and parenting: Trends of the 1990s. In: Macura, M., MacDonald, A.L., and Haug, W. (eds.). The new demographic regime. Population challenges and policy responses. Geneva: United Nations: 63-94.

Brandt, M., Haberkern, K., and Szydlik, M. (2009). Intergenerational help and care in Europe. European Sociological Review 25(5): 585-601. doi:10.1093/esr/jen076.

Bytheway, B. (1974). A statistical trap associated with family size. Journal of Biosocial Science 6(1): 67-72. doi:10.1017/S0021932000009512.

Carnes, B.A. and Olshansky, S.J. (2007). A realist view of aging, mortality, and future longevity. Population and Development Review 33(2): 367-381. doi:10.1111/j.1728-4457.2007.00172.x.

Christensen, K., Doblhammer, G., Rau, R., and Vaupel, J.W. (2009). Ageing populations: The challenges ahead. Lancet 374(9696): 1196-1208. doi:10.1016/S0140-6736(09)61460-4.

Clarke, L. (1995). Family care and changing family structure: Bad news for the elderly? In: Allen, I. and Perkins, E. (eds.). The future of family care. London: HMSO: $19-50$. 
Connidis, I.A. (2010). Family ties and aging. Second edition. Thousand Oaks: Pine Forge Press.

Daatland, S.O. and Herlofson, K. (2003). Norms and ideals about elder care. In: Lowenstein, A. and Ogg, J. (eds.). OASIS. Old age and autonomy: The role of service systems and intergenerational family solidarity. Final report. Haifa: Center for research and study of aging, University of Haifa.

De Jong Gierveld, J. and Dykstra, P.A. (2006). Impact of longer life on care giving from children. In: Zeng, Y., Crimmins, E.M., Carrière, Y., and Robine, J.-M. (eds.). Longer life and healthy aging. Dordrecht: Springer: 239-259. doi:10.1007/1-4020-4032-6_15.

Devolder, D. (2005). Fertility trends in Europe: Parity analysis. Paper presented at the IUSSP XXV International Population Conference, Tours, France, July 18-23, 2005.

Doblhammer, G. and Hoffmann, R. (2010). Gender differences in trajectories of health limitations and subsequent mortality. A study based on the German Socioeconomic Panel 1995-2001 with a mortality follow-up 2002-2005. Journal of Gerontology: Social Sciences 65B(4): 482-491. doi:10.1093/geronb/gbp051.

Dorbritz, J. (2008). Germany: Family diversity with low actual and desired fertility. Demographic Research 19(17): 557-598. doi:10.4054/DemRes.2008.19.17.

Dubas, J.S. (2001). How gender moderates the grandparent-grandchild relationship: A comparison of kin-keeper and kin-selector theories. Journal of Family Issues 22(4): 478-492. doi:10.1177/019251301022004005.

Dykstra, P.A. (2003). Implications of socio-demographic changes for individual lives and families. Invited presentation at the EURESCO conference on the Second Demographic Transition in Europe, Spa, Belgium, June 19-24, 2003.

Dykstra, P.A. (2009). Childless old age. In: Uhlenberg, P. (ed.). International Handbook on Population Aging. Springer: 671-690.

Dykstra, P.A. and Hagestad, G.O. (2007a). Roads less taken. Developing a nuanced view of older adults without children. Journal of Family Issues 28(10): 12751310. doi:10.1177/0192513X07303822.

Dykstra, P.A. and Hagestad, G.O. (2007b). Childlessness and parenthood in two centuries: Different roads - different maps? Journal of Family Issues 28(11): 1518-1532. doi:10.1177/0192513X07303881. 
Dykstra, P.A. and Komter, A.E. (2006). Structural characteristics of Dutch kin networds. In: Dykstra, P.A., Kalmijn, M., Knijn, T.C.M., Komter, A.E., Liefbroer, A.C., and Mulder, C.H. (eds.). Family solidarity in the Netherlands. Amsterdam: Dutch University Press: 21-37.

Eggebeen, D.J. (1992). Family structure and intergenerational exchanges. Research on Aging 14(4): 427-447. doi:10.1177/0164027592144001.

Eisenberg, A.R. (1988). Grandchildren's perspectives on relationships with grandparents: The influence of gender across generations. Sex Roles 19(3-4): 205-217. doi:10.1007/BF00290155.

Esping-Andersen, G. and Sarasa, S. (2002). The generational conflict reconsidered. Journal of European Social Policy 12(1): 5-21. doi:10.1177/ 0952872002012001560.

European Foundation for the Improvement of Living and Working Condition (1995). Who will care? - Future prospects for family care of older people in the European Union. Luxembourg: Office for Official Publications of the European Communities.

Farkas, J.I. and Hogan, D.P. (1995). The demography of changing intergenerational relationships. In: Bengtson, V.L., Schaie, K.W., and Burton, L.M. (eds.). Adult Intergenerational Relations. New York: Springer Publishing Company: 1-18.

Finch, J. and Mason, J. (1993). Negotiating family responsibilities. London: Routledge.

Freedman, V.A., Crimmins, E., Schoeni, R.F., Spillmann, B.C., Aykan, H., Kramarow, E., Land, K., Lubitz, J., Manton, K., Martin, L.G., Shinberg, D., and Waidman, T. (2004). Resolving inconsistencies in trends in old-age disability: Report from a technical working group. Demography 41(3): 417-441. doi:10.1353/ dem.2004.0022.

Freedman, V.A., Wolf, D.A., Soldo, B.J., and Stephen, E.H. (1991). Intergenerational transfers: A question of perspective. The Gerontologist 31(5): 640-647. doi:10.1093/geront/31.5.640.

Frejka, T. (2008). Parity distribution and completed family size in Europe: Incipient decline of the two-child family model? Demographic Research 19(4): 47-72. doi:10.4054/DemRes.2008.19.4.

Frejka, T. and Sardon, J.-P. (2006). First birth trends in developed countries: Persisting parenthood postponement. Demographic Research 15(6): 147-180. doi:10.4054/DemRes.2006.15.6. 
Gee, E.M. and Gutman, G.M. (eds.). (2000). The overselling of population aging. Apocalyptic demography, intergenerational challenges, and social policy. Toronto: Oxford University Press.

Goldstein, J.R., Sobotka, T., and Jasilioniene, A. (2009). The end of "lowest-low" fertility? Population and Development Review 35(4): 663-699. doi:10.1111/ j.1728-4457.2009.00304.x.

Grünheid, E. and Scharein, M.G. (2011). On developments in the mean joint lifetimes of three- and four-generation families in Western and Eastern Germany - a model calculation. Comparative Population Studies. (preprint). doi:10.4232/10.CPoS-2011-01en.

Hagestad, G.O. (1981). Problems and promises in the social psychology of intergenerational relations. In: Fogel, R.W., Hatfield, E., Kiesler, S.B., and Shanas, E. (eds.). Aging, stability and change in the family. New York: Academic Press: 11-46.

Hagestad, G.O. (1985). Continuity and connectedness. In: Bengtson, V.L. and Robertson, J.F. (eds.). Grandparenthood. Beverly Hills, CA: Sage: 31-48.

Hagestad, G.O. (2001). Adult intergenerational relationships. In: Gender and Generation Programme: Exploring future research and data collection options. New York and Geneva: UNECE and United Nations Population Fund: 125-143.

Hagestad, G.O. (2006). Transfers between grandparents and grandchildren: The importance of taking a three-generation perspective. Zeitschrift für Familienforschung 18(3): 315-332.

Hagestad, G.O. (2008a). The book-ends: Emerging perspectives on children and old people. In: Saraceno, C. (ed.). Families, ageing and social policy. Intergenerational solidarity in European welfare states. Cheltenham, UK: Edward Elgar: 20-37.

Hagestad, G.O. (2008b). Changes in children's age and generation mosaics: Challenges to research and policy. In: Leira, A. and Saraceno, C. (eds.). Childhood: Changing contexts. Comparative Social Research Vol. 25. Bingley, UK: Emerald: 113-132. doi:10.1016/S0195-6310(07)00004-X.

Hagestad, G.O. and Herlofson, K. (2010). Aldring [Ageing]. In: Frønes, I. and Kjølsrød, L. (eds.). Det norske samfunn. Oslo: Gyldendal akademisk: 414-434.

Hagestad, G.O. and Uhlenberg, P. (2007). The impact of demographic changes on relations between age groups and generations: A comparative perspective. In: 
Schaie, K.W. and Uhlenberg, P. (eds.). Social structures: Demographic changes and the well-being of older persons. New York: Springer Publishing Co.: 239261.

Harper, S. (2003). Changing families as European societies age. European Journal of Sociology 44(2): 155-184. doi:10.1017/S0003975603001231.

Hill, R., Foote, N., Aldous, J., Carlson, R., and MacDonald, R. (1970). Family development in three generations. Cambridge, Mass.: Schenkman Publishing Co.

Jacobzone, S., Cambois, E., Chaplain, E., and Robine, J.M. (1999). The health of older persons in OECD countries: Is it improving fast enough to compensate for population ageing? OECD Labour Market and Social Policy Occasional Papers 37. (Paris: OECD). doi:10.1787/066187831020.

Jensen, A.-M., Kjørholt, A.T., Qvortrup, J., and Sandbæk, M. (2004). Childhood and generation in Norway: Money, time and space. In: Jensen, A.-M., Ben-Arieh, A., Conti, C., Kutsar, D., Phádraig, M.N.G., and Nielsen, H.W. (eds.). Children's Welfare in Ageing Europe, vol. 1. Trondheim: Norsk senter for barneforskning: 335-457.

Keck, W. and Saraceno, C. (2008). Grandchildhood in Germany and Italy: An exploration. In: Leira, A. and Saraceno, C. (eds.). Childhood: Changing contexts. Comparative Social Research Vol. 25. Bingley, UK: Emerald: 133163. doi:10.1016/S0195-6310(07)00005-1.

Kennedy, G.E. (1990). College students' expectations of grandparent and grandchild role behaviours. The Gerontologist 30(1): 43-48. doi:10.1093/geront/30.1.43.

Kinsella, K. and Taeuber, C.M. (1993). An Aging World II. Washington D.C.: U.S. Bureau of the Census, U.S. Government Printing Office, International Population Reports (P25/92-3).

Kinsella, K. and Velkoff, V.A. (2001) An aging world: 2001. Washington D.C.: U.S. Census Bureau, U.S. Government Printing Office. (Series P95/01-1).

Knipscheer, C.P.M. (1992). Interdependency among the generations within the family: A sociological approach. In: Bouma, H. and Graafmans, J.A.M. (eds.). Gerontechnology. Amsterdam: IOS Press: 39-50.

Knipscheer, C.P.M., Dykstra, P., Utasi, A., and Cxeh-Szombathy, L. (2000). Aging and the family. In: Beets, G. and Miltényi, K. (eds.). Population ageing in Hungary 
and the Netherlands: A European perspective. Amsterdam: Thela Thesis Publishers: 181-199.

Kohli, M. and Albertini, M. (2009). Childlessness and intergenerational transfers: What is at stake? Ageing and Society 29(8): 1171-1183. doi:10.1017/ S0144686X09990341.

Kohli, M., Künemund, H., and Lüdicke, J. (2005). Family structure, proximity and contact. In: Börsch-Supan, A., Brugiavini, A., Jürges, H., Mackenbach, J., Siegrist, J., and Weber, G. (eds.). Health, ageing and retirement in Europe First results from the Survey on Health, Ageing and Retirement in Europe. Mannheim: MEA: 164-170.

Kreager, P. and Schröder-Butterfill, E. (eds.). (2004). Ageing without children: European and Asian perspectives. New York: Berghahn Books.

Kreyenfeld, M., Scholz, R., Peters, F., and Wlosnewski, I. (2010). The German Birth Order Register - Order-specific data generated from perinatal statistics and statistics on out-of-hospital births 2001-2008. Rostock: Max Planck Institute for Demographic Research, MPIDR Working Paper (WP 2010-010).

Langford, C.M. (1982). Family size from the child's point of view. Journal of Biosocial Science 14(3): 319-327. doi:10.1017/S0021932000014164.

Lowenstein, A., Katz, R., Mehlhausen-Hassoen, D., and Prilutzky, D. (2002). The research instruments in the OASIS project. Haifa: The center for research and study of aging, University of Haifa.

Lutz, W., Goujon, A., Samir, K.C., and Sanderson, W. (2007). Reconstruction of populations by age, sex and level of educational attainment for 120 countries for 1970-2000. Vienna Yearbook of Population Research 2007: 193-235. doi:10.1553/populationyearbook2007s193.

Lutz, W., Skirbekk, V., and Testa, M.R. (2006). The low fertility trap hypothesis: Forces that may lead to further postponement and fewer births in Europe. Vienna Yearbook of Population Research 2006: 167-192. doi:10.1553/ populationyearbook2006s115.

Matthews, S.H. and Sprey, J. (1985). Adolescents' relationships with grandparents: An empirical contribution to conceptual clarification. Journal of Gerontology 40(5): 621-626. doi:10.1093/geronj/40.5.621. 
Matthews, S.H. and Sun, R. (2006). Incidence of four-generation family lineages: Is timing of fertility or mortality a better explanation? The Journals of Gerontology Series B: Psychological Sciences and Social Sciences 61(2): S99-S106.

Monk, A. (1983). Family supports in old age. Home Health Care Services Quarterly 3(3-4): 101-110. doi:10.1300/J027v03n03_07.

Morrison, P.A. (1990). Demographic factors reshaping ties to family and place. Research on Aging 12(4): 399-408. doi:10.1177/0164027590124002.

Murphy, M. and Grundy, E. (2003). Mothers with living children and children with living mothers: The role of fertility and mortality in the period 1911-2050. Population Trends 112: 36-44.

Murphy, M., Martikainen, P., and Pennec, S. (2006). Demographic change and the supply of potential family supporters in Britain, Finland and France in the period 1911-2050. European Journal of Population 22(3): 219-240. doi:10.1007/ s10680-006-9003-8.

OECD (2007). Trends in severe disability among elderly people: Assessing the evidence in 12 OECD countries and the future implications. Paris: OECD, OECD Health Working Papers (No. 26).

Oeppen, J. and Vaupel, J.W. (2002). Broken limits to life expectancy. Science 296(5570): 1029-1031. doi:10.1126/science.1069675.

Ogg, J. and Renaut, S. (2006). The support of parents in old age by those born during 1945-1954: A European perspective. Ageing \& Society 26(5): 723-743. doi:10.1017/S0144686X06004922.

Oksuzyan, A., Juel, K., Vaupel, J.W., and Christensen, K. (2008). Men: Good health and high mortality. Sex differences in health and aging. Aging Clinical and Experimental Research 20(2): 91-102.

Olshansky, J. and Carnes, B.A. (2009). The future of human longevity. In: Uhlenberg, P. (ed.). International Handbook on Population Aging. Springer: 731-745.

Pennec, S. (1997). Four-generation families in France. Population: An English Selection 9: 75-100.

Pickard, L. (2002). The decline of intensive intergenerational care of older people in Great Britain, 1985-1995. Population Trends 110: 31-41.

Preston, S. (1976). Family sizes of children and family sizes of women. Demography 13(1): 105-114. doi:10.2307/2060423. 
Puur, A., Sakkeus, L., Põldma, A., and Herm, A. (2011). Intergenerational family constellations in contemporary Europe: Evidence from the Generations and Gender Survey. Demographic Research 25(4): 135-172. doi:10.4054/ DemRes.2011.25.4.

Robertson, A. (1990). The politics of Alzheimer's disease: A case study in apocalyptic demography. International Journal of Health Services 20(3): 429-442. doi:10.2190/C8AE-NYC1-2R98-MHP1.

Rosenthal, C.J. (2000). Ageing families: Have current changes and challenges been "oversold"? In: Gee, E.M. and Gutman, G.M. (eds.). The overselling of population aging. Apocalyptic demography, intergenerational challenges, and social policy. Toronto: Oxford University Press: 45-63.

Rosenthal, C.J., Martin-Matthews, A., and Matthews, S.H. (1996). Caught in the middle? Occupancy in multiple roles and help to parents in a national probability sample of Canadian adults. Journal of Gerontology: Social Sciences 51B(6): S274-S283. doi:10.1093/geronb/51B.6.S274.

Rossi, A.S. and Rossi, P.H. (1990). Of human bonding. Parent-child relations across the life course. New York: Aldine de Gruyter.

Samir, K.C., Barakat, B., Goujon, A., Skirbekk, V., Sanderson, W., and Lutz, W. (2010). Projections of populations by level of educational attainment, age and sex for 120 countries for 2005-2050. Demographic Research 22(15): 383-472. doi:10.4054/DemRes.2010.22.15.

Sanderson, W.C. and Scherbov, S. (2010). Remeasuring aging. Science 329(5997): 1287-1288. doi:10.1126/science.1193647.

Sardon, J.-P. (2006). Recent demographic trends in the developed countries. Population 57(1): 111-156. doi:10.2307/3246629.

Schei, B. and Bakketeig, L.S. (eds.). (2007). Kvinner lider - menn dør [Women suffer men die]. Oslo: Gyldendal Akademisk.

Schoeni, R.F., Freedman, V.A., and Martin, L.G. (2008). Why is late-life disability declining? The Milbank Quarterly 86(1): 47-89. doi:10.1111/j.14680009.2007.00513.x.

Sobotka, T. (2004). Is lowest-low fertility in Europe explained by the postponement of childbearing? Population and Development Review 30(2): 195-220. doi:10.1111/j.1728-4457.2004.010_1.x. 
Soldo, B.J. and Hill, M.S. (1995). Family structure and transfer measures in the Health and Retirement Study. The Journal of Human Resources 30 (Special issue on Health and Retirement Study: Data quality and early results): S108-S137. doi:10.2307/146280.

Sørensen, A.-M. (2005). Family structure, gender roles and social inequality. In: Svallfors, S. (ed.). Analyzing inequality. Life chances and social mobility in comparative perspective. Palo Alto, CA: Stanford University Press: 108-128.

Spitze, G. and Logan, J. (1991). Sibling structure and intergenerational relations. Journal of Marriage and the Family 53(4): 871-884. doi:10.2307/352994.

Spitze, G. and Ward, R.A. (1998). Gender variations. In: Szinovacs, M.E. (ed.). Handbook on grandparenthood. Westport, CT: Greenwood Press: 113-127.

Stuifbergen, M.C., Van Delden, J.J.M., and Dykstra, P.A. (2008). The implications of today's family structures for support giving to older parents. Ageing \& Society 28(3): 413-434. doi:10.1017/S0144686X07006666.

Tanturri, M.L. and Mencarini, L. (2008). Childless or childfree? Paths to voluntary childlessness in Italy. Population and Development Review 34(1): 51-77. doi:10.1111/j.1728-4457.2008.00205.x.

Tennstedt, S.L., Crawford, S.L., and McKinley, J.B. (1992). Is family care on the decline? A longitudinal investigation of the substitution of formal long-term care services for informal care. The Milbank Quarterly 71(4): 601-624. doi: $10.2307 / 3350421$.

Uhlenberg, P. (1993). Demographic change and kin relationships in later life. In: Maddox, G.L. and Lawton, M.P. (eds.). Annual Review of Gerontology and Geriatrics. Focus on kinship, aging, and social change. New York: Springer: 219-238.

Uhlenberg, P. (1995). Commentary: Demographic influences on intergenerational relationships. In: Bengtson, V.L., Schaie, K.W., and Burton, L.M. (eds.). Adult Intergenerational Relations. New York: Springer Publishing Company: 19-25.

Uhlenberg, P. (1996). Mortality decline in the twentieth century and supply of kin over the life course. The Gerontologist 36(5): 681-685. doi:10.1093/geront/36.5.681.

Uhlenberg, P. and Cheuk, M. (2008). Demographic change and the future of informal caregiving. In: Szinovacs, M. and Davey, A. (eds.). Caregiving contexts. Cultural, familial and societal implications. New York: Springer Publishing Company: 9-33. 
United Nations (2002). World Population Ageing 1950-2050. New York: United Nations, Department of Economic and Social Affairs, Population Division.

United Nations (2007a). Generations and gender programme: Concepts and guidelines. New York and Geneva: United Nations.

United Nations (2007b). World Population Ageing 2007. New York: United Nations, Department of Economic and Social Affairs, Population Division.

United Nations (2009). World population prospects: The 2008 revision. New York: United Nations.

van Gaalen, R., Dykstra, P.A., and Flap, H. (2008). Intergenerational contact beyond the dyad: The role of the sibling network. European Journal of Ageing 5(1): 1929. doi:10.1007/s10433-008-0076-6.

van Imhoff, E. and Post, W. (1998). Microsimulation methods for population projection. Population - An English selection 10(1): 97-138. (Special issue: New Methodological approaches in the Social Sciences).

Véron, J., Pennec, S., and Légaré, J. (2007). Introduction. In: Véron, J., Pennec, S., and Légaré, J. (eds.). Ages, generations and the social contract. The demographic challenges facing the welfare state. Dordrecht, The Netherlands: Springer: 1-13.

Wagner, M., Schütze, Y., and Lang, F.R. (1999). Social relationships in old age. In: Baltes, P.B. and Mayer, K.U. (eds.). The Berling Aging Study. Aging from 70 to 100. Cambridge: Cambridge University Press: 282-301.

Watkins, S.C., Menken, J.A., and Bongaarts, J. (1987). Demographic foundations of family change. American Sociological Review 52(3): 346-358. doi:10.2307/2095354.

Wenger, G.C. (2001). Ageing without children: Rural Wales. Journal of Cross-Cultural Gerontology 16(1): 79-109. doi:10.1023/A:1010699231743.

Wenger, G.C., Dykstra, P.A., Melkas, T., and Knipscheer, K.C.P.M. (2007). Social Embeddedness and lage-life parenthood: Community activity, close ties and support networks. Journal of family issues 28(11): 1419-1456. doi:10.1177/ 0192513 X07303895.

Wolf, D.A. (1994). The elderly and their kin: Patterns of availability and access. In: Martin, L.G. and Preston, S.H. (eds.). Demography of aging. Washington, D.C.: National Academy Press: 146-194. 